\title{
Evaluations of Accounting Professionals and Accounting Academicians Regarding to International Financial Reporting Standards: A Comparative Analysis ${ }^{*}$
}

\author{
Naim Ata ATABEY ${ }^{1}$, Halil AKMESE ${ }^{2}$ \\ ${ }^{1}$ Faculty of Economics and Administrative Sciences, Selcuk University, Turkey \\ ${ }^{2}$ Social Sciences Vocational School of Higher Education, Department of Accounting and Taxation, Selcuk University, Turkey \\ ataatabey@gmail.com, halilakmese@gmail.com
}

\begin{abstract}
Adoption of International Financial Reporting Standards (IFRS) in some countries led to various problems and stimulated the research efforts regarding to this issue. Turkey, as being a developing country, is trying to integrate to the global economy by amending new regulations such as Turkish Trade Code 2011 or by adopting recently developed guidelines such as IFRS. As a result of the adaptation efforts to the world economy and changing regulations there might be dissension or consensus on emerging issues such as the adoption and mandatory use of IFRS. Major aim of this study is to reveal the personal evaluations of accounting professionals and accounting academicians, whom might be considered as implementation and conception parties respectively regarding to accounting and IFRS. A short questionnaire is directed to 66 accounting professionals and 36 academicians in Konya/Turkey in order to determine the general tendency of professionals and academicians towards IFRS. Results are processed by means of SPPS software and findings are compared quantitatively. This study is designed to shed light on the situation rather than seeking a remedy for a specific problem.

Index Terms - Accounting, IFRS, IFRS Adoption.
\end{abstract}

\section{Introduction}

IFRS have seriously been discussed and adopted by many countries and authorities after the Enron Case. International standard setters and regulators of some countries have been forcing the implementation of IFRS in practice [1]. Turkey is also in the process of adopting IFRS since 2005, and 2013 is the date that the standards have came into effect for both public and non-public firms [2]. Many international institutions such as International Organization of Securities Commissions (IOSCO), International Federation of Accountants (IFAC), Securities and Exchange Commission (SEC), Basel Committee, the World Bank, International Monetary Fund (IMF) and European Commission support the adoption of IFRS [3].

The Capital Markets Board of Turkey (CMB) which is the regulation-setting body for registered firms in Turkish capital markets played the initiating role in the development of national accounting standards for listed firms prior to 2008, including the voluntary adoption of IFRS in 2003 and the mandatory adoption in 2005. In 2008, the CMB assigned its standard-setting role to the Turkish Accounting Standards
Board (TASB). The latter issued Turkish Accounting Standards (TAS) which are directly translated versions of IFRS. The TASB was merged with the Public Oversight, Accounting and Auditing Standards Authority established in 2011. This authority now issues TAS [4].

Standard setters, regulators, and policy-makers all have a vital interest in the effect of financial reporting on the economy. This interest is due to the economic consequences associated with financial information. Financial information influences investors' behavior with respect to portfolio selection, which in turn affects security prices and, therefore, the terms on which a firm obtains additional financing [5].

\section{Findings}

A questionnaire is designed and directed to the accounting professionals from different experience levels and different professional status. Similarly, the same questions are directed to accounting academicians because they are perceived as the change initiators and conception leaders with respect to emerging issues such as adoption of new applications.

Due to the limitations of conference format 8 questions of the questionnaire are analyzed and interpreted in this study. One of the questions is designed to understand the tendency of participants if they believed the IFRS will contribute to and enhance the international and financial relations or not. Results might be summarized as follows:

TABLE 1 Contribution of IFRS to economic and financial relations.

\begin{tabular}{|c|c|c|c|c|c|c|}
\hline \multirow{2}{*}{ Question 1 } & \multicolumn{5}{|c|}{$\begin{array}{c}\text { IFRS will contribute to and enhance the international } \\
\text { economic and financial relations? }\end{array}$} \\
\cline { 2 - 7 } & \multicolumn{2}{|c|}{ Agree } & \multicolumn{2}{c|}{ Disagree } & \multicolumn{2}{c|}{ Partly Agree } \\
\hline & Freq. & Percent & Freq. & Percent & Freq. & Percent \\
\hline Academicians & 30 & 83,3 & 0 & 0 & 6 & 16,7 \\
\hline Professionals & 29 & 43,9 & 13 & 19,7 & 24 & 36,4 \\
\hline Total & 59 & 57,8 & 13 & 12,7 & 30 & 29,4 \\
\hline
\end{tabular}

It is apparent that a big majority of the participants agreed the proposition that IFRS will contribute to and enhance the international economic and financial relations. But the

\footnotetext{
* This work is partially supported by Scientific Research Projects (BAP) Grant \# 14701018 to Halil Akmese.
} 
percentage rate of agreement for academicians is nearly two fold of the percentage rate of accounting professionals. Meaning that accounting academicians might be evaluated as more receptive and open regarding to new regulations. On the other hand it might be claimed that most of the accounting professionals are not as much as interactive with the foreign parties as it is for accounting academicians. Meaning that perception and acceptance levels of academicians regarding to similar adoption and application processes might be higher than the perception and acceptance levels of accounting professionals.

Participants are asked if they thought that the IFRS might be mandated in application to all companies or not. Results are summarized in table 2 below. Almost all of the academicians agreed totally $(69.4 \%)$ or partly $(27.8 \%)$ that the use of IFRS by all companies should be mandated. On the other hand agreement totally or partially and disagreement to this statement by accounting professionals dispersed equally (nearly one third for each type of opinion). Meaning that two thirds of professionals agreed the mandating of IFRS while one third rejected this proposition. This might be interpreted as the slight resistance which might be caused by new procedures and applications that will be brought by the mandatory use of IFRS. Interesting point on this question is that except 1 accounting academician the rest agreed this proposition. This might be interpreted as academicians believe that switching from national accounting standards might be achieved by mandating the new set of IFRS to all companies operating within the jurisdictional area.

TABLE 2 Mandatory use of IFRS.

\begin{tabular}{|c|c|c|c|c|c|c|}
\hline \multirow{2}{*}{ Question 2 } & \multicolumn{5}{|c|}{ Use of IFRS by all companies should be mandatory. } \\
\cline { 2 - 7 } & \multicolumn{2}{|c|}{ Agree } & \multicolumn{2}{c|}{ Disagree } & Partly Agree \\
\hline & Freq. & Percent & Freq. & Percent & Freq. & Percent \\
\hline Academicians & 25 & 69,4 & 1 & 2,8 & 10 & 27,8 \\
\hline Professionals & 21 & 31,8 & 23 & 34,8 & 22 & 33,3 \\
\hline Total & 46 & 45,1 & 24 & 23,5 & 32 & 31,4 \\
\hline
\end{tabular}

In order to test and validate the results gathered from the second question, all participants are asked if they agreed or not that new challenges related to the application of IFRS will accompany the adoption process. And the results gathered supported the views of participants. As it is shown in table 3, $50 \%$ of the accounting academicians disagreed this proposition and approximately one fourth of the accounting professionals disagreed. This might be interpreted as the higher tendency rates of accounting academicians towards the adoption process of IFRS.

TABLE 3 Challenges accompanied to the adoption of IFRS.

\begin{tabular}{|l|c|c|c|c|c|c|}
\hline \multirow{2}{*}{ Question 3 } & \multicolumn{4}{|c|}{ New challenges will accompany the adoption of IFRS. } \\
\cline { 2 - 7 } & \multicolumn{2}{|c|}{ Agree } & \multicolumn{2}{c|}{ Disagree } & \multicolumn{2}{c|}{ Partly Agree } \\
\hline & Freq. & Percent & Freq. & Percent & Freq. & Percent \\
\hline Academicians & 16 & 44,4 & 18 & 50 & 2 & 5,6 \\
\hline Professionals & 30 & 45,5 & 16 & 24,2 & 20 & 30,3 \\
\hline
\end{tabular}

\begin{tabular}{|l|l|l|l|l|l|l|}
\hline Total & 46 & 45,1 & 34 & 33,3 & 22 & 21,6 \\
\hline
\end{tabular}
Next question aims to understand the evaluations of accounting academicians and professionals regarding to the easiness and explanatory qualifications of new financial reporting standards compatible with IFRS. Table 4 summarizes the responses. The results of this question seems to be some conflicting. Because, nearly two thirds of the accounting professionals agreed totally or partly that new financial report formats are easy to read and more explanatory than the conventional ones. On the other hand half of the accounting academicians disagreed this statement. This might be due to the differentiating understanding and use of financial statements. One of the major differences in financial report usage is that accounting professionals evaluate the statements if they are able to explain the financial position and some additional issues such as social responsibility and similar subtitles. On the other hand accounting professionals evaluate the financial statements technically if they are able to serve the tax and some other bureaucratic issues such as incentives and governmental informative issues.

TABLE 4 Qualifications of new reports prepared in accordance with IFRS compared to conventional repots in accordance with national standards.

\begin{tabular}{|c|c|c|c|c|c|c|}
\hline \multirow{2}{*}{ Question 4 } & \multicolumn{6}{|c|}{$\begin{array}{c}\text { Financial reports prepared compatible with IFRS are easy to } \\
\text { read and explanatory enough regarding to the accounting } \\
\end{array}$} \\
\cline { 2 - 7 } & \multicolumn{2}{|c|}{ Agree } & \multicolumn{2}{c|}{ Disagree } & Partly Agree \\
\hline & Freq. & Percent & Freq. & Percent & Freq. & Percent \\
\hline Academicians & 10 & 27,8 & 18 & 50 & 2 & 5,6 \\
\hline Professionals & 22 & 45,5 & 16 & 24,2 & 20 & 30,3 \\
\hline Total & 32 & 45,1 & 34 & 33,3 & 22 & 21,6 \\
\hline
\end{tabular}

TABLE 5 Educational efforts of governmental and non-governmental organizations regarding to the adoption of IFRS.

\begin{tabular}{|c|c|c|c|c|}
\hline \multirow{2}{*}{ Question 5 } & \multicolumn{4}{|c|}{$\begin{array}{c}\text { Efforts made by governmental and non-governmental } \\
\text { organizations in order to educate and inform the accounting } \\
\text { professionals and accounting academicians are sufficient. }\end{array}$} \\
\cline { 2 - 5 } & \multicolumn{3}{|c|}{ Agree } & \multicolumn{2}{c|}{ Disagree } \\
\hline & Freq. & Percent & Freq. & Percent \\
\hline Academicians & 11 & 30,6 & 25 & 64,4 \\
\hline Professionals & 22 & 33,3 & 44 & 66,7 \\
\hline Total & 33 & 32,4 & 69 & 67,6 \\
\hline
\end{tabular}

It is apparent from the responses that two thirds of both accounting academicians and accounting professionals evaluate the educational and informative efforts made by governmental and non-governmental organization as insufficient. Regarding to this issue it might be claimed that major role with respect to the adoption process belongs to the Public Oversight, Accounting and Auditing Standards Authority and their efforts do not meet the expectations of other parties. It is obvious that the evaluations of accounting academicians and accounting professionals regarding to the educational and informative efforts are overlapping.

Another question is designed to understand the participative efforts of accounting academicians and accounting professionals regarding to the IFRS related 
educational or informative events. Table 6 below summarizes the results.

TABLE 6 Participation rates of accounting academicians and accounting professionals to the informative and educational events related to IFRS.

\begin{tabular}{|c|c|c|c|c|}
\hline \multirow{2}{*}{ Question 6 } & \multicolumn{4}{|c|}{ Have you attended educational or informative events related } \\
& \multicolumn{4}{|c|}{ Yes IFRS? } \\
\cline { 2 - 5 } & Freq. & Percent & Freq. & Percent \\
\hline & 32 & 88,9 & 4 & 11,1 \\
\hline Academicians & 28 & 42,4 & 38 & 57,6 \\
\hline Professionals & 60 & 58,8 & 42 & 41,2 \\
\hline Total & & & & No \\
\hline
\end{tabular}

It is apparent from the responses that the rate of participation to educational and informative events of accounting academicians (nearly 90\% ) are much more higher than the rate related to accounting professionals $(42,4 \%)$. This might be due to the priority given to academicians when the case is any kind of knowledge or know-how transfer. Moreover academicians ability to access international resources and informative or educational activities is much more easier due to their linguistic abilities. Higher rate of language abilities might increase the participative efforts to such events.

In order to understand the preferences of participants regarding to information sources, they are required to indicate among the presented choices.

TABLE 7 Information sources for following the developments related to IFRS.

\begin{tabular}{|l|c|c|c|c|c|c|}
\hline \multirow{2}{*}{ Question 7 } & \multicolumn{6}{|c}{$\begin{array}{r}\text { Please indicate the most preferred source of information for } \\
\text { following the developments related to IFRS. }\end{array}$} \\
\cline { 2 - 8 } & \multicolumn{2}{|c|}{$\begin{array}{c}\text { Accounting } \\
\text { Academicians }\end{array}$} & \multicolumn{2}{c|}{$\begin{array}{c}\text { Accounting } \\
\text { Professionals }\end{array}$} & \multicolumn{2}{c|}{ Total } \\
\hline & Freq. & Freq. & Freq. & Freq. & Freq. & Percent \\
\hline Books & 10 & 27,8 & 3 & 4,55 & 13 & 12,8 \\
\hline Internet & 18 & 50 & 41 & 62,12 & 59 & 57,8 \\
\hline $\begin{array}{l}\text { Professional } \\
\text { Organizations }\end{array}$ & 1 & 2,8 & 9 & 13,64 & 10 & 9,8 \\
\hline $\begin{array}{l}\text { Conferences } \\
\text { \&Seminars }\end{array}$ & 6 & 16,7 & 8 & 12,12 & 14 & 13,7 \\
\hline Journals & 1 & 2,8 & 5 & 7,58 & 6 & 5,9 \\
\hline
\end{tabular}

As it is observable from table 7 the most preferred source of information both for accounting academicians and accounting professionals is internet. More than half of all respondents report that their primary information source is internet. Conferences \& Seminars and books are the second and third information sources respectively. Journals and periodicals receive the least attention as information source with a small minority preferring these publications. From the responses it is apparent that regardless of their professional status most of the respondents prefer internet based sources. This might be due to the dynamic nature of internet based sources. Internet based sources are appropriate for continuous updating and requires less time and costs might be less with respect to other types of information sources.

In the next question respondents are asked if they thought that the use of IFRS by economically and financially developed countries will lead to higher rates of acceptance by other countries. As it is observable from table 8 more than 80 percent of the accounting academicians and more than half of the accounting professionals believed that the acceptance of IFRS by developed countries will result in higher adoption rates by other countries.

TABLE 8 Adoption of IFRS by other jurisdictional areas.

\begin{tabular}{|c|c|c|c|c|}
\hline \multirow{2}{*}{ Question 8 } & \multicolumn{4}{|c|}{$\begin{array}{c}\text { Do you think that the use of IFRS by economically and } \\
\text { financially developed countries will lead to higher rates of } \\
\text { acceptance and adoption by other countries? }\end{array}$} \\
\cline { 2 - 5 } & \multicolumn{3}{|c|}{ Yes } & No \\
\hline & Freq. & Percent & Freq. & Percent \\
\hline Academicians & 30 & 83,3 & 6 & 16,7 \\
\hline Professionals & 43 & 65,2 & 23 & 34,8 \\
\hline Total & 73 & 71,6 & 29 & 28,4 \\
\hline
\end{tabular}

The overlapping thoughts relating to the common acceptance of IFRS might be accomplished by leading acceptance of developed countries. And this phenomenon might be explained by the fact that developed countries are playing an important role in determining the systematical approaches and in determining the frameworks of global issues.

\section{Conclusions}

As it is indicated at the beginning, this study aims to shed light on the perceptions and evaluations of accounting academicians and accounting professionals regarding to the adoption process of International Financial Reporting Standards. It might be concluded that big majority of academicians and professionals agreed that the adoption of IFRS will contribute to the development of international financial and economic relations. But the evaluations of academicians and professionals differ when the case is mandatory use of IFRS. Accounting professionals seem to be hesitated to some degree due to the expected problems and application difficulties which are thought to be caused during the transition process. As an indicative evaluation nearly half of the participants both academicians and professionals stated that some problems and challenges will accompany the adoption process especially regarding to the application of IFRS. One of the hesitations related to the new set of standards seems to be aroused by the expected easiness and explanatory qualifications of financial statements prepared in accordance with IFRS. Responses of academicians and professionals indicate that financial statements in compliance with IFRS do not meet the expectations of both parties. regarding to the educational efforts of governmental and nongovernmental organizations it might be concluded that both academicians and professionals do not believe that the efforts made by these authorities are not sufficient. Internet based sources seems to be the most popular way of tracking 
developments and emerging issues related to IFRS. Consecutive sources for gaining knowledge and keeping abreast of status quo seems to be books and various professional meetings such as conferences and seminars.

As a result it might be concluded that despite some slight divergences in specific issues such as mandatory use of IFRS and qualifications of financial reports, evaluations of accounting academicians and accounting professionals regarding to the new set of International Financial Reporting standards and the adoption process of these standards seems to be overlapping. Further studies relating to the diverging thoughts of academicians and professionals with respect to IFRS might be carried out in order to determine the reasons of these divergences.

\section{References}

[1] R. Pekdemir, and A. Turel, "IFRS 2005 in Turkey; Can we see the evidences on the financial reports of the companies listed?", 2007, http://mpra.ub.uni-muenchen.de/29838/MPRA Paper No. 29838, posted on 24 March 2011.

[2] S. Karğın, R. Aktaş, , "Strategic Thinking Skills of Accountants During Adoption of IFRS and The New Turkish Commercial Code: A Survey from Turkey" $8^{\text {th }}$ Strategic Management Conference, pp.128-137, 2012.

[3] A. Alsuhaibani, "The Expected Impact of IFRS Adoption on Saudi Arabia Based on Lessons from Other Countries: A Focus on the Telecommunication Business", WCBEM, pp.1190-1198, 2012.

[4] İ. Misırlığlu, J. Tucker, and O. Yükseltürk, "Does Mandatory Adoption of IFRS Guarantee Compliance" The International Journal of Accounting, vol. 48, issue. 3, pp. 327-363, September 2013.

[5] V. Palea, "IAS/IFRS and Financial Reporting Quality: Lessons From the European Experience", China Journal of Accounting Research, vol.4, issue 4, pp. 247-263, December 2013. 